\title{
PENGELOLAAN ZAKAT DI NEGARA SUDAN
}

\author{
Aulia Candra Sari \\ Peneliti pada Baznas Kabupaten Jepara \\ e-mail: auliachandra11@gmail.com
}

\begin{abstract}
Sudan is one of the countries that use Islamic sharia in its government, so zakat as one of the pillars of Islam gets special attention from the Sudanese government. This article examines the management of zakat in Sudan based on established regulations. The results show that zakat is an obligation that must be paid by the people of Sudan and will be given sanctions for people who are reluctant to pay. Zakat management in Sudan is based on the Zakat Act of 2001. The implementation of zakat management in Sudan has the following characteristics: first, zakat is handled directly by the government. Second, the Zakat Board as a manager is independent. Third, Sudan implements the Federal system. And fourth, Sudan has a broad figh view of the object of zakat.
\end{abstract}

Keywords: Zakat, Sudan, and Zakat Management Regulation

\section{Pendahuluan}

Sudan merupakan negara Islam, artinya hukum Islam dijadikan sebagai pegangan hukum. Sudan tergolong unik di antara negara-negara Islam. jika negara islam yang lain 
selalu terkenal stigma fundamentalisme, Sudan justru bangga menjadikan Islam sebagai landasan bernegara.

Dapat dikatakan, Sudan hanyalah sebuah negara dan bukan bangsa. ada sekitar 100 lebih bahasa dan dialek yang digunakan masyarakat sehari-hari. Mereka terpecah oleh banyak etnis, tetapi tidak ada satupun etnis yang menjadi mayoritas. Terpecah pula oleh wilayah dan kesukuan. Selebihnya, populasi di utara kawasan didominasi oleh budaya Arab sedangkan di Selatan oleh budaya Afrika lebih berkembang. Menghadapai segala perbedaan ini, kaum mayoritas berpendapat, satu hal yang dapat mempersatukan islam hanyalah islam. dan untuk tujuan ini, Sudan menerapkan Islamisasi.

Umumnya ketika mendengar kata Sudan atau sebuah Negara bernama Sudan tentulah gambaran yang keluar dari benak kita adalah miskin. Sebagai negara yang menerapkan syariat Islam sebagai hukum negara, sudah tentu Sudan mengatur tentang kewajiban zakat. Zakat sebagai bentuk distribusi harta dari orang kaya kepada orang miskin, memiliki peranan penting dalam pemerataan kekayaan. Sehingga harta tidak berada pada orang kaya saja, tetapi juga fakir miskin mendapat haknya dari para aghniya'.

Di negara Sudan, zakat merupakan kewajiban yang harus ditunaikan oleh muzaki dan akan diberikan sanksi jika tidak menunaikannya. Zakat secara khusus di kelola oleh Dewan Zakat selaku lembaga independen yang dibentuk oleh pemerintah. Artikel ini akan membahas mengenai pengelolaan zakat di Sudan dengan menganalisis Undang-Undang Zakat Sudan tahun 2001.

\section{Pembahasan}

\section{Gambaran umum negara Sudan}

Secara geografis Sudan merupakan bagian dari subregionalisme maghribi. Maghribi adalah Afrika Utara kawasan Timur Tengah yang terletak di benua Afrika bagian Utara, meliputi: Maghrib Aqsa (paling barat), Maghrib Wustha (Tengah) dan Maghrib Adna (Timur). Apabila diklasifikasikan ke dalam sub-regionalisme maka Sudan menjadi bagian dari sub-regionalisme Magrib Adna. Sudan terletak di bagian Timur 
Laut honua Afrika, terbentang antara $4^{\circ}$ dan $23^{\circ}$ Lintang Utara, serta ${ }^{22}$ dan ${ }^{38}$ Bujur Timur. Sudan merupakan negara terluas kedua di benua Afrika. Total wilayah Sudan mencakup 1.882.000 $\mathrm{km}$ dan merupakan 8,3\% dari seluruh luas benua Afrika. Luas wilayah laut dan sungai $129,813 \mathrm{~km}$ serta luas daratan 1.752.187 km (https://www.academia.edu/13123375/).

Populasi penduduk Sudan merupakan populasi yang paling berbeda dengan negara-negara lain di benua Afrika. Hal ini dikarenakan adanya dua kebudayaan besar yaitu Arab dan dan orang Afrika yang berkulit hitam, dengan ratusan kelompok etnis, suku, dan bahasa. Penduduk Sudan berasal dari berbagai macam kelompok etnis yang berbeda, yaitu etnis Afrika sebesar 52\%, Arab $39 \%$, Beja 6\%, dan lain-lain sebanyak 3\%. Penduduk di wilayah utara Sudan mayoritas memeluk agama Islam (70\%), sebanyak 5\% memeluk agama Kristen dan kebanyakan berdomisili di Selatan Sudan, sementara $25 \%$ penduduk lainnya masih memegang teguh kepercayaan asli. Sebagian besar masyarakat Sudan berbahasa Arab, disamping juga masih menggunakan bahasa suku mereka seperti Nubian, Beja, Ta Bedawie, Fur, Nuban, dan juga dialek Nilotic dan Nilo-Hamitic (CIA fact book: Sudan Country profile).

\section{Masuknya Islam di Sudan}

Migrasi bangsa Arab pertama terjadi pada abad sembilan ketika bangsa Mesir berkerumun di wilayah Selatan sampai akhirnya mereka menemukan ladang emas di Allaqi yang terletak di antara sungai Nil dan Laut Merah. Baru pada abad ke dua belas dan tiga belas gelombang migrasi Arab Badui meningkat. Mereka berbaur dengan keluarga lokal melaluo suksesi anak-anak mereka yang secara matrilineal mewarisi kepemimpinan lokal.

Di sebelah selatan terdapat masyarakat pengembala yang berasal dari wilayah Blue Nile yang terkenal dengan nama suku Funj yang tengah bergerak ke Utara. Kemudian mereka bersama pemimpinnya, Amara Dungas, mampu mengalahkan kerajaan Kristen di Alwa pada tahun 1504 dan menjadikan Sinnar sebagai ibu kota Kerajaan Funj. Di bagian Utara negara Funj baru ini berbatasan dengan masyarakat Arab - Muslim, yang kemudian mereka mengadakan hubungan perdagangan 
dengan bahasa Arab sebagai Lingua Franca. Perkembangan bahasa Arab sebagai bahasa persatuan ini, pada akhirnya (yakni pada abad 18) menjadikan dokumen-dokumen kenegaraanpun menggunakan bahasa Arab (http://file.upi.edu/Direktori/ FPIPS/M_K_D_U/196708282005011).

Penyebaran Islam di kerajaan Funj di samping meraksuk di kalangan elit penguasa dan komunitas perdagangan, juga karena adanya migrasi ulama dan orang-orang suci muslim ke daerah ini.

Kemajuan kerajaan Funj ini menarik perhatian para Ulama dari Mesir, Afrika Utara dan Arabia, yang secara lokal mereka menyandang predikat keahlian di bidang al-Quran, hukum Islam, dan Sufi.

Para faqih (para ulama itu) memiliki pengaruh yang kuat karena kemampuannya untuk bernegosiasi dan mengkritik penguasa. Mereka mendirikan tempat-tempat pendidikan untuk mengajarkan al-Quran, hukum dan teologi kepada pemuda sejak dini. Para faqih di timur Sudan ini merangkap sebagai anggota tarikat-tarikat sufi. Ada beberapa tarikat yang tersebar di negero ini, di antaranya tarikat Shahiliyah tersebar di wilayah ini pada abad lima belas, tarikat Qadiriyah pada pertengahan abad ke enam belas, dan tarikat Majdhubiyah pada abad ke delapan belas.

Dalam perjalanannya yang panjang, pada abad delapan belas kerajaan Funj ini dilandan disintegrasi. System perkawinan dan kepangeranan menjadi dinasti-dinasti otonom. Perdagangan mulai dikuasai oleh pedagang kelas menengah, dan para faqih mendapat mandate dari masyarakat petani, yang semua itu berkontribusi untuk menggerogoti kekuasaan sultan. Kerajaan ini akhirnya tumbang karena penyerbuan bangsa Mesir pada 18201821, yang kemudian membuka jalan terbukanya/dikenalnya administrasi keislaman.

Pada akhir abad ke delapan belas Abd-Rahman al-Rasyid (1786/7-1800/1) mengkosolidasikan kesultanan Darfur di sekitar komplek istana yang dinamakan al-Fashir. Dengan demikian alFashir merupakan pusat kegiatan pemerintahan dan pelatihanpelatihan serta perdagangan. 
Pada akhir abad delapan belas para pedagang dan tokoh suci muslim mendapat kekuasaan dari dinasti Darfur untuk memerintah secara semi independent. Dengan demikian, akhirnya mereka secara particular berhasil mengkonsolidasikan kekuasaan lokal mereka.

Islamisasi Sudan bagian timur ini berjalan dengan baik berkat dorongan para faqih sehingga pada abad Sembilan belas sultan memasukkannya ke dalam control birokasi.

\section{Ajaran zakat}

Sudan sebagai salah satu negara Arab Afrika resmi memberlakukan syariat Islam pada tahun 1989. Penerapan syariat Islam ini meliputi segala aspek politik dan ekonomi serta sosial budaya di mana seluruh aktivitas negara harus disesuaikan dengan prinsip-prinsip dasar al-Quran yang menjadi sumber utama perundang-undangan. Sebagai salah satu rukun Islam, zakat mendapat perhatian khusus dari pemerintah.

Zakat menurut bahasa berarti berkah, bersih, dan berkembang. Dinamakan berkah, karena dengan membayar zakat, hartanya akan bertambah atau tidak berkurang. Dinamakan bersih, karena dengan membayar zakat, harta dan dirinya menjadi bersih dari kotoran dan dosa yang menyertainya yang disebabkan oleh harta yang dimilikinya tersebut terdapat hak-hak orang lain. Dinamakan berkembang karena dengan membayar zakat hartanya dapat mengembang sehingga tidak bertumpuk di satu tempat atau pada seseorang (Hikmat dan Hidayat, 2008: 2-3).

Sedangkan zakat menurut terminologi adalah sejumlah harta tertentu yang diwajibkan oleh Allah SWT untuk diberikan kepada orang yang berhak menerima zakat (Mustahiq) yang disebutkan di dalam al-Quran. Selain itu, juga bisa berarti sejumlah harta tertentu yang diberikan kepada orang yang berhak menerimanya dengan syarat-syarat tertentu (Hikmat dan Hidayat, 2008: 3).

Mengutip pendapat Yusuf Qardhawi, kata zakat dalam bentuk ma'rifah (definisi) disebut tiga puluh kali di dalam alQuran, diantaranya dua puluh tujuh kali disebutkan dalam satu ayat bersama shalat, dan hanya satu kali disebutkan dalam 
konteks yang sama dengan shalat tetapi tidak di dalam satu ayat (Qardhawi, 2011: 39-40), yaitu firman-Nya: "Dan orang-orang yang giat menunaikan zakat", setelah ayat: "Orang-orang yang khusyu' dalam bershalat".

Sebagian ahli mengatakan bahwa kata zakat yang selalu dihubungkan dengan shalat terdapat pada 82 tempat di dalam al-Quran. Menurut Yusuf Qardhawi jumlah ini terlalu dibesarbesarkan, sehingga tidak sesuai dengan perhitungan sebelumnya. Tetapi jika yang dimaksudkan adalah kata-kata lain yang sama maksudnya dengan zakat seperti al-infaq'pemberian', al-ma'un 'barang-barang kebutuhan', dan tha'am, al-miskin 'memberi makan orang miskin' dan lain-lain, maka tidak diketahui jumlahnya secara pasti tetapi berkisar antara 32 sampai 82 tempat.

Di antara dasar hukum zakat adalah al-Quran surat atTaubah ayat 103 yang artinya: "Ambillah zakat dari sebagian harta mereka, dengan zakat itu kamu membersihkan dan mensucikan mereka dan mendoakanlah untuk mereka. Sesungguhnya doa kamu itu (menjadi) ketentraman jiwa bagi mereka. Dan Allah maha Mendengar lagi maha Mengetahui." (QS. At-Taubah: 103)

Dari ayat ini dapat ditegaskan bahwa yang memungut zakat adalah kepala negara atau wakil atas nama kepala negara, sesuai dengan sunnah Rasul dan penerapan konkrit para khalifah empat. Ayat ini menunjukkan bahwa yang mengambil zakat adalah Nabi Muhammad sendiri, lalu mendoakan mereka (Qardhawi, 2011: 734).

Abu Bakar mengambil langkah-langkah tegas untuk megumpulkan zakat dari semua umat Islam termasuk Badui yang kembali memperlihatkan tanda-tanda pembangkangan speninggal Rasulullah SAW. Ia memerintahkan pasukannya untuk menyerang suku-suku pembangkang tersebut (Muhammad Hasan, 2011: 11).

Sebagaimana pemerintahan Rasulullah, pemerintahan Umar bin Khattab memposisikan zakat sebagai sumber utama pendapatan negara. zakat dijadikan ukuran fiscal utama dalam rangka memecahkan masalah ekonomi secara umum. Pengenaan zakat atas harta berarti menjamin penanaman kembali dalam perdagangan dan perniagaan yang tidak perlu dilakukan dalam 
pajak pendapatan. Hal ini juga akan member keseimbangan antara perdagangan dan pengeluaran (Muhammad Hasan, 2011: 12).

Pada masa pemerintahan Utsman bin Affan dilaporkan bahwa untuk mengamankan dari gangguan dan masalah dalam pemeriksaan kekayaan yang tidak jelas oleh beberapa pengumpul yang nakal, Utsman mendelegasikan kewenangan kepada para pemilik untuk menaksir kepemilikannya sendiri (Muhammad Hasan, 2011: 13).

Adapun pada masa pemerintahan Ali, pengelolaan zakat terjadi secara individu dikarenakan keadaan pemerintah yang tidak stabil sehingga kepercayaan masyarakat kepada pemerintah pun mulai menurun (Tim Kemenag RI, 2013: 24).

Adapun dasar hukum zakat dari hadits, di antaranya adalah: "Islam didirikan di atas lima dasar: mengikrarkan bahwa tidak ada Tuhan selain Allah dan Muhammad adalah utusan Allah, mendirikan shalat, membayar zakat, berpuasa pada bulan Ramadhan, dan berhaji bagi siapa yang mampu." (Muttafaqun 'Alaih)

Menurut Didin Hafidhuddin, secara umum dan global alQuran menyatakan bahwa zakat diambil dari setiap harta yang kita miliki, seperti dikemukakan dalam surat at-Taubah ayat 103 , dan juga diambil dari setiap hasil usaha yang baik dan halal, seperti juga digambarkan dalam surat al-Baqarah ayat 267 (Didin, 2002: 15).

Sejalan dengan ketentuan ajaran Islam yang selalu menetapkan standar umum pada setiap kewajiban yang dibebankan kepada umatnya, maka dalam penetapan harta menjadi sumber atau objek zakat pun terdapat ketentuan yang harus dipenuhi (Didin, 2002: 18).

Adapun persyaratan harta menjadi sumber atau obyek zakat, adalah sebagai berikut: Pertama, Harta tersebut harus didapatkan dengan cara yang baik dan halal. Artinya, harta yang haram, baik substansi bendanya maupun cara mendapatkannya, jelas tidak dapat dikenakan kewajiban zakat, karena Allah SWT tidak akan menerimanya. Kedua, harta tersebut berkembang atau berpotensi untuk dikembangkan, seperti melalui kegiatan usaha, perdagangan, melalui pembelian saham, atau ditabungkan, 
baik dilakukan sendiri maupun bersama orang atau pihak lain. Ketiga, milik penuh, yaitu harta tersebut berada di bawah control dan di dalam kekuasaan pemiliknya, atau seperti menurut sebagian ulama bahwa harta itu berada di tangan pemiliknya, di dalamnya tidak tersangkut dengan hak orang lain, dan ia dapat menikmatinya (Didin, 2002: 20-25).

Keempat, menurut jumhur ulama, harus mencapai nishab, yaitu jumlah minimal yang menyebabkan harta terkena kewajiban zakat. Menurut Didin Hafidhuddin, persyaratan adanya nishab ini merupakan suatu keniscayaan sekaligus merupakan suatu kemaslahatan, sebab zakat itu diambil dari orang yang kaya (mampu) dan diberikan kepada orang-orang yang tidak mampu, seperti fakir miskin. Indicator kemampuan itu harus jelas, dan nishab lah merupakan indiaktornya. Kelima, sumber-sumber zakat tertentu, seperti perdagangan, peternakan, emas dan perak, harus sudah berada atau dimiliki ataupun diusahakan oleh muzakki dalam tenggang waktu satu tahun. Sedangkan zakat pertanian, tidak terkait dengan ketentuan haul (berlalu waktu satu tahun), ia harus dikeluarkan pada saat memetiknya atau memanennya jika mencapai nishab, sebagaimana dikemukakan dalam surat alAn'am ayat 4.

Keenam,sebagian ulama mazhab Hanafi mensyaratkan kewajiban zakat setelah terpenuhi kebutuhan pokok, atau dengan kata lain, zakat dikelurakan setelah terdapat kelebihan dan kebutuhan hidup sehari-hari yang terdiri atas kebutuhan sandang, pangan, dan papan. Mereka berpendapat bahwa yang dimaksud dengan kebutuhan pokok adalah kebutuhan yang jika tidak dipenuhi akan mengakibatkan kerusakan dan kesengsaraan hidup. Tetapi sebagian ulama berpendapat bahwa amatlah sulit untuk menentukan atau mengukur seseorang itu telah terpenuhi kebutuhan pokoknya atau belum, karena kebutuhan pokok setiap orang ternyata berbeda-beda, demikian pula dengan kebutuhan pokok antar daerah. Oleh sebab itu, syarat nishab dan an-nama' itu sesungguhnya sudah cukup.

Berikut ini adalah macam-macam harta yang wajib dizakati menurut al-Quran dan Hadits: Pertama, binatang ternak (unta, sapi, kambing). Dalam berbagai hadits ditemukan bahwa 
hewan ternak yang wajib dikeluarkan zakatnya setelah memenuhi persyaratan tertentu, ada tiga jenis, yaitu unta, sapi, dan domba atau kambing. Hal ini didasarkan pada hadits Rasulullah yang artinya: "Dari Abu Dzar berkata: Aku datang kepada Rasulullah SAW dan beliau bersabda: Dan demi diriku yang berada pada kekuasaanNya, atau demi zat yang tiada Tuhan selain-Nya, atau sebagaimana ia bersumpah. Tidaklah seseorang memiliki unta, sapi atau domba, lalu tidak menunaikan haknya (zakatnya) kecuali binatang itu akan datang pada hari kiamat kepadanya, dalam keadaan lebih besar dan lebih gemuk dari biasanya. Hewan-hewan itu akan menginjak-nginjak dengan kakinya atau menanduknya dengan tanduknya. Apabila selesai pada barisan yang terakhir, ia dikembalikan pada barisan yang pertama, sehingga ditetapkan hukuman di antara sesama manusia lainnya." (HR Bukhari).

Adapun persyaratan utama kewajiban zakat pada hewan ternak adalah sebagai berikut: Pertama, mencapai nishab. Syarat ini berkaitan dengan jumlah minimal hewan yang dimiliki, yaitu lima ekor untuk unta, 30 ekor untuk sapi, dan 40 ekor untuk kambing atau domba. Kedua, telah melewati waktu satu tahun (haul). Ketiga, digembalakan di tempat penggembalaan umum. Keempat, tidak dipergunakan untuk keperluan pribadi pemiliknya dan tidak pula dipekerjakan (Didin, 2002: 31).

Kedua, emas dan perak. emas dan perak adalah harta yang wajib dikeluarkan zakatnya apabila telah mencapai nishab. Nishab emas adalah 20 dinar atau setara dengan 93,6 gram. Ini artinya 1 dinar $=4,68$ gram emas, maka $20 \times 4,68=93,6$ gram. Zakat yang wajib dikeluarkan adalah 2,5\%. Sedangkan nishab perak adalah 200 dirham atau setara dengan 624 gram perak. 1 dirham setara dengan 3,12 gram perak, maka $200 \times 3,12=624$ gram perak. Zakat yang wajib dikeluarkan adalah 2,5\% (M. Syafe'ei, 2009: 27). Pendapat lain ada yang mengatakan bahwa nishab emas adalah 85 gram dan nishab perak adalah 595 gram. 1 dinar $=4,25$ gram, maka nishab emas adalah $20 \times 4,25$ gram $=85$ gram emas. Adapun 1 dirham $=2,975$ gram emas, maka nishab perak adalah $200 \times 2$, 975 gram = 595 gram emas (http://pusat.baznas.go.id/zakatemas-perak-dan-uang/). Pendapat terakhir inilah yang diikuti BAZNAS. 
Kewajiban zakat ini didasarkan pada hadits Nabi Muhammad yang berarti: "Pada emas dan perak, zakat keduanya seperempat puluh (2,5\%)". (HR Bukhari)

Ketiga, zakat pertanian dan perkebunan. Hasil pertanian seperti padi, gandum, jagung, dan makanan pokok lainnya yang mengenyangkan serta tahan disimpan lama, wajib dikeluarkan zakatnya apabila telah mencapai nishab. Nishabnya adalah 5 wasaq (930 liter). Rasulullah SAW bersabda: "Tidak ada zakat pada biji-bijian dan buah-buahan sehingga mencapai 5 wasaq." (HR. Muslim). Adapun besar zakat yang dikeluarkan, apabila system pengairan pertanian dan perkebunan itu memanfaatkan tadah hujan maka zakatnya adalah 10\%. Namun, jika system pengairannya menggunakan mesin maka besar zakat yang harus dikeluarkan adalah 5\% (http:// pusat.baznas.go.id/zakat-emas-perak-danuang/). Zakat pertanian tidak disyaratkan adanya haul. Jadi, sekali panen sudah mencapai nishab maka wajib zakat.

Keempat, harta perniagaan. harta benda yang diperniagakan atau diperdagangkan wajib dkeluarkan zakatnya apabila telah mencapai nishab. Hal ini didasarkan pada sabda Rasulullah SAW yang artinya: "Samurah berkata : Rasulullah memerintahkan kepada kami agar kami mengeluarkan zakat barang yang disediakan untuk dijual." (HR Abu Daud) Adapun nishabnya diqiyaskan kepada nishab emas, yaitu 93,6 gram (pendapat lain 85 gram), dan besar zakat yang harus dibayarkan adalah 2,5\% dan berlalu satu tahun (haul) (M. Syafe'ei: 2009: 27).

Kelima, hasil tambang. Hasil tambang berupa emas dan perak apabila sampai nishab, wajib dikeluarkan zakatnya 2,5\% pada waktu itu juga dengan tidak disyaratkan sampai satu tahun (haul) sebagaimana pada pertanian dan perkebunan. Hal ini berdasarkan hadits Nabi Muhammad: "Bahwasanya Rasulullah SAW telah memungut zakat dari hasil tambang di negeri Qabaliyah". (HR Abu Daud dan Hakim). Sementara hasil tambang lain, seperti baru bara, minyak bumi, gas bumi, dan sebagainya, zakatnya diqiyaskan dengan zakat emas. Nishab emas adalah 93,6 gram (pendapat lain mengatakan 85 gram emas), kemudian dirupiahkan. Jika sudah mencapau jumlah rupiah nishab emas, wajib dikeluarkan zakatnya 2,5\% (M. Syafe'ei, 2009: 29). 
Keenam, harta terpendam (rikaz). Harta terpendam termasuk salah satu harta yang wajib dikeluarkan zakatnya. Zakat yang wajib dibayarkan sebesar $20 \%$ dari keseluruhan nilai harta yang terpendam tersebut. Sabda Rasulullah SAW: "Abu Hurairah berkata: Rasulullah SAW telah bersabda: Zakat rikaz seperlima." (HR Bukhari Muslim). Rikaz tidak dipersyaratkan sampai satu tahun (haul), melainkan wajib dikeluarkan saat itu juga seperti zakat hasil tambang.

Ketujuh, zakat hasil usaha kontemporer. Hukum hasil zakat usaha kontemporer menjadi kawasan ijtihad para ulama, yaitu dengan cara beristinbath hukum dengan mengqiyaskannya kepada dalil yang terkait dengan harta benda wajib zakat tersebut (M. Syafe'ei, 2009: 30). Secara umum ketentuan tentang kewajiban zakat hasil usaha kontemporer didasarkan pada firman Allah surat al-Baqarah ayat 267.

Menurut para ulama, kalimat ma kasabtum pada ayat 267nmenunjukkan arti segala hasil usaha yang baik dan diperoleh secara sah dan halal. Artinya, apapun jenis usaha, baik di bidang produksi maupun jasa yang dilakukan oleh seorang Muslim atau Muslimah, sepanjang dikerjakan dengan cara-cara yang baik dan tidak melanggar hukum agama, wajib dikeluarkan zakatnya (M. Syafe'ei, 2009: 31).

Menurut Didin Hafidhuddin, criteria-kriteria yang digunakan untuk menetapkan sumber atau objek zakat yang meskipun secara langsung tidak dikemukakan dalam al-Quran dan hadits, akan tetapi kini menjadi objek zakat yang penting adalah sebagai berikut: Pertama, sumber zakat tersebut masih dianggap hal yang baru, sehingga belum mendapatkan pembahasan secara mendalam dan terinci. Berbagai macam kitab fiqih terdahulu belum banyak membicarakannya, misalnya zakat profesi. Kedua, sumber zakat tersebut merupakan ciri utama ekonomi modern, sehingga hampir disetiap negara sudah maju maupun negara berkembang, merupakan sumber zakat yang cukup potensial. Contohnya zakat investasi property, zakat perdagangan mata uang, dan lain-lain (Didin, 2002: 91-92).

Ketiga, sementara ini zakat selalu dikaitkan dengan kewajiban kepada perorangan, sehingga badan hukum yang 
melakukan kegiatan usaha tidak dimasukkan ke dalam sumber zakat. Padahal zakat itu di samping harus dilihat dari sudut muzaki, juga harus dilihat dari sudut hartanya. Karenanya sumber zakat badan hukum perlu mendapat pembahasan, misalnya zakat perusahaan.

Keempat, sumber zakat sektor modern yang mempunyai nilai yang sangat signifikan yang terus berkembang dari waktu ke waktu dan perlu mendapat perhatian serta keputusan status zakatnya, seperti usaha tanaman anggramek, burung wallet, ikan hias, dan lain sebagainya. Demikian pula sektor rumah tangga modern pada segolongan tertentu kaum muslimin yang berkecukupan, bahkan cenderung berlebih-lebihan (israf), yang tercermin dari jumlah dan harga kendaraan serta kasesoris rumah tangga yang dimilikinya.

\section{Sudan dan pengelolaan zakat}

Jika mengacu pada masa Rasulullah dan Khulafaur Rasyidin, pengelolaan zakat seharusnya ditangani langsung oleh pemerintah dengan membentuk semacam departemen khusus yang menangani urusan zakat. Kata "khudz" (ambillah) menunjukkan pengertian bahwa dalam sebuah negara harus ada lembaga khusus yang mengurusi zakat. Mereka bertugas memungut zakat dari orang-orang yang telah terkena kewajiban berzakat. Kemudian mengelolanya secara amanah dan professional untuk disalurkan kepada yang berhak, baik dalam bentuk pemberian secara tunai maupun dalam bentuk programprogram pemberdayaan dan pengentasan kemiskinan.

Sudan sebagai salah satu negara yang menerapkan syariat Islam sebagai peratuan negara, mewajibkan zakat sebagai kewajiban yang didasarkan pada undang-undang wajib zakat dan institusi yang menanganinya.

Sebelum diterapkannya Undang-Undang zakat tahun 2001, yang menjadi dasar peraturan pengelolaan zakat di Sudan adalah Undang-Undang Zakat tahun 1990. UU zakat tahun 2001 menjelaskan bahwa pengelolaan zakat di Sudan dilakukan oleh Dewan Zakat sebagai operator, dan Majelis Tinggi Kepengurusan Zakat sebagai legislator. Artinya, Dewan Zakat bekerja berdasarkan 
arahan dan keputusan dari Majelis Tinggi Kepengurusan Zakat (Undang-undang Zakat Sudan Tahun 2001).

Dewan Zakat merupakan lembaga independen yang dibentuk oleh pemerintah Sudan untuk melakukan pengumpulan, pengelolaan, dan pendistribusian zakat. Mengenai jumlah anggota Dewan Zakat, tidak disebutkan dalam UU. Dewan Zakat ada dua yaitu Dewan Zakat Pusat dan Dewan Zakat Provinsi. Untuk Dewan Zakat Pusat yang menjadi penanggung jawab operasional kepada Majelis Tinggi Kepengurusan Zakat adalah Sekretaris Jenderal, sedangkan untuk Dewan Zakat Provinsi yang menjadi penanggung jawab operasional kepada Majelis Tinggi Kepengurusan Zakat Provinsi adalah Sekretaris Dewan Zakat Provinsi. Baik Dewan Zakat Pusat maupun Dewan Zakat Provinsi, keduanya tunduk dan bekerja sesuai dengan kebijakan dan rencana Majelis Tinggi Kepengurusan Zakat maupun Majelis Kepengurusan Zakat provinsi sesuai dengan tingkatannya.

Majelis Tinggi Kepengurusan Zakat merupakan lembaga tertinggi yang menjalankan tugas pengawasan umum dalam mewujudkan tujuan Dewan Zakat. Adapun susuan Majelis Tinggi Kepengurusan Zakat terdiri dari Menteri sebagai ketua, Sekretaris Jenderal merangkap anggota dan pemutus kebijakan, dan anggota yang berjumlah maksimal 20 orang yang ditentukan oleh Presiden melalui Keputusan Presiden (Kepres) atas rekomendasi Menteri, dan juga pendapat Ulama, muzaki serta perangkat negara. Sama halnya dengan Dewan Zakat, Majelis Tinggi Kepengurusan Zakat juga ada di tingkat pusat dan provinsi. Di tingkat provinsi, susunannya terdiri dari: (1) 13 orang anggota yang dipilih oleh Majelis Tinggi Kepengurusan Zakat Provinsi atas rekomendasi Gubernur dengan tidak meninggalkan pendapat ulama, muzaki dan perangkat khusus di tingkat Provinsi, (2) Seorang Sekretaris dengan merangkap sebagai anggota dan pemutus kebijakan, 3) Seorang Menteri yang dipilih oleh Majelis Tinggi Kepengurusan Zakat Provinsi dari ke 13 orang anggota tersebut.

Kewajiban zakat tergantung pada kewarganegaraan dan agama seseorang, karena itu zakat diwajibkan untuk seluruh warga negara sudan yang beragama islam dan memiliki harta yang cukup, baik mereka di dalam negeri ataupun diluar negeri. 
Serta harta warga negara orang sudan yang sedang berada diluar negeri wajib dizakati (Abdullah Khatib, 2013: 64).

Untuk warga non-sudan yang beragama Islam, berdomisili atau kerja di sudan, dikenakan wajib zakat. Dan apabila pemilik harta benda tidak berada di dalam negeri pada saat jatuh tempo, pembayaran bisa diwakilkan oleh penanggung jawab benda tersebut.

Masuknya dua pertimbangan kewarganegaraan dan domisili menjadi syarat wajib zakat memiliki beberapa kelebihan (Abdullah Khatib, 2013: 64-65): Pertama, bertambah banyak pemasukan dan zakat karena zakat diambil dari harta benda milik muslim baik harta tersebut didalam negeri atau di luar negeri. Demikian juga harta milik orang asing yang muslim yang sedang dikembangkan di negara Sudan.

Kedua, mewujudkan kesatuan umat islam yaitu dengan jalan memberikan perlakuan yang sama antara warga sudan dan non Sudan yang berdomisili disudan sehingga dapat menjalin kasih sayang, persaudaraan dan saling bahu membahu dalam kehidupan sehari-hari dan dalam upaya merealisasikan syariah Islam yang telah terakomodasi dalam UU resmi negara.

Adapun harta yang wajib dizakati menurut UU tersebut adalah barang tambang, barang perdagangan, emas, perak, uang, dan surat berharga. Untuk nishab dan tarif zakatnya mengikuti zakat emas. Selanjutnya yang dikenakan zakat adalah hasil pertanian, barang temuan, dan hewan ternak. Sudan juga telah memperluas obyek harta wajib zakat yaitu harta mustaghollat dan zakat penghasilan (mustafad).

Al-Mustaghallat adalah setiap barang yang asalnya tetap dan menghasilakan pemasukan serta bertambah kemanfaatannya. Penghasilan dari mustaghallat meliputi pengolahan hasil pertanian, hasil pengolahan produksi hewan, penghasilan bersih dari jasa transportasi serta pendapatan lainnya yang ditentukan oleh Komisi Fatwa.

Undang-undang zakat juga mewajibkan zakat atas penghasilan dari profesi mencakup gaji para pegawai dan professional serta penghasilan sampingan lainnya. Pembayaran 
zakat dilakukan disaat penerimaan penghasilan tersebut dengan prasyarat penghasilan tersebut melebihi kebutuhan pokok minimal, dan zakat yang dikeluarkan tarifnya 2,5\%. Standar kebutuhan pokok sendiri ditetapkan oleh Majelis Fatwa.

Dalam hal pendistribusian zakat, untuk mustahik di Sudan sesuai dengan ketentuan agama yaitu 8 asnaf yang tertulis pada pembahasan sebelumnya, berdasarkan skala prioritas dan kebutuhan mustahik.

Dikarenakan pembayaran zakat di Sudan bersifat wajib, maka dalam UU tersebut dijelaskan pula sanksi mengenai: pertama, setiap individu yang menolak maupun menghindar dari membayar zakat. Mereka akan diberi hukuman denda sebesar zakat yang harus dikeluarkan sehingga ia harus membayar zakat dua kali lipat. Kedua,setiap individu yang menolak member laporan ataupun dokumen yang diminta oleh Dewan Zakat, maka didenda sebesar $10 \%$ dari zakat yang seharusnya dibayarkan. Denda tersebut dibayarkan kepada Dewan Zakat atau Dewan Zakat Provinsi sesuai lingkup kewenangannya.

Di Sudan, kewajiban membayar zakat menjadi pengurang kewajiban pajak pribadi dengan menunjukkan surat tanda lunas zakat yang diterbitkan oleh Sekretaris Jenderal maupun Sekretaris sesuai dengan wilayahnya.

Berbeda dengan di Indonesia yang mengutamakan asas transparansi dan keterbukaan dalam pengelolaan zakat, di Sudan Dewan Zakat dalam hal ini amil tidak diperbolehkan mempublikasikan informasi berkenaan dengan zakat dan alokasinya, justru tindakan tersebut dianggap sebagai criminal dan akan dihukum pidana bagi yang melakukannya.

Penerapan pengelolaan zakat di Sudan memiliki karakteristik sebagai berikut: pertama, zakat ditangani langsung pemerintah. Sebagaimana dalam surat at Taubah ayat 103 yang memerintahkan agar zakat ditangani langsung oleh negara, maka Sudan memiliki UU khusus tentang zakat. Dengan adanya UU zakat yang kedudukannya cukup kuat, maka bagi yang telah kena kewajiban zakat namun tidak menunaikannya maka akan terkena sanksi. Kedua, Dewan Zakat sebagai lembaga independen yang dibentuk pemerintah Sudan, mempunyai wewenang penuh dalam 
menangani perzakatan, mulai dari pemungutan, pengelolaan, dan penedistribusian zakat. Ia harus bertanggung jawab kepada Presiden melalui Direktorat Jenderal. Ketiga,menerapkan system Federal. Artinya, di setiap provinsi memiliki Dewan Zakat masing-masing. Dan jika suatu provinsi telah tercukupi kebutuhannya dari zakat tersebut, maka dialihkan ke provinsi lain yang membutuhkan. Keempat,memiliki pandangan fiqih yang luas. Dewan Zakat menetapkan pemungutan zakat tidak hanya terbatas pada enam jenis harta saja saja (emas dan perak/ naqdaan, pertanian dan perkebunan, niaga dan perdagangan, barang tambang dan barang temuan). Namun juga memasukkan harta wajib zakat di masa kontemporer seperti al-mustaghallat dan al-mustafad. Tentu hal ini demi asas keadilan dan terwujudnya kemaslahatan umat utamanya fakir miskin.

\section{Simpulan}

Pengelolaan zakat di Sudan berdasarkan UU Zakat tahun 2011. Dalam UU tersebut dijelaskan bahwa yang berhak mengelola zakat adalah Dewan Zakat Pusat dan Dewan Zakat Provinsi sesuai dengan kewenangannya. Dalam pelaksanaanya, lembaga ini berjalan berdasarkan arahan serta peraturan dari Majelis Tinggi Kepengurusan Zakat Pusat dan Majelis Tinggi Kepengurusan Zakat Provinsi. Lembaga ini bertanggung jawab kepada presiden melalui Sekretaris Jenderal. Penerapan pengelolaan zakat di Sudan memiliki karakteristik sebagai berikut: pertama, zakat ditangani langsung pemerintah. Sebagaimana dalam surat at-Taubah ayat 103 yang memerintahkan agar zakat ditangani langsung oleh negara, maka Sudan memiliki Undang-Undang khusus tentang zakat. Kedua, Dewan Zakat sebagai lembaga independen yang dibentuk pemerintah Sudan, mempunyai wewenang penuh dalam menangani perzakatan, mulai dari pemungutan, pengelolaan, dan pendistribusian zakat. Ketiga, menerapkan system Federal. Artinya, di setiap provinsi memiliki Dewan Zakat masingmasing. Keempat, memiliki pandangan fiqih yang luas. Dewan Zakat menetapkan pemungutan zakat tidak hanya terbatas pada enam jenis harta saja saja (emas dan perak/naqdaan, pertanian dan perkebunan, niaga dan perdagangan, barang tambang dan 
barang temuan). Namun juga memasukkan harta wajib zakat di masa kontemporer seperti al-mustaghallat dan al-mustafad.

\section{Daftar Pustaka}

Abdullah Khatib Nadahari, Pengelolaan Zakat di Dunia Muslim, Jurnal Ekonomi dan Hukum Islam, STAI Darul Ulum Banyuwangi, Vol. 3, No. 2, 2013.

CIA fact book: Sudan Country profile. http://www.cia.gov/ library/publications/the-world-factbook/geos/su.html diakses 25 Des 2016 pukul 08:19 WIB

Departemen Agama RI, Al-Quran dan Terjemahannya, Proyek Pengadaan Kitab Suci al-Quran, Jakarta, 1982.

Didin Hafidhuddin, Zakat dalam Perekonomian Modern, Gema Insani, Jakarta, 2002.

Hikmat Kurnia dan Hidayat, Panduan Pintar Zakat, Qultum Media, Jakarta, 2008.

http:// file.upi.edu/Direktori/Fpips/M_k_d_u/196708282005011

-Elan_sumarna/Artikel/Dunia_Islam_di_Afrika_Timur. pdf diakses 13 Oktober 2017.

http://pusat.baznas.go.id/zakat-emas-perak-dan-uang/ diakses 07 Oktober 2017, pukul 20.14 WIB.

https:/ / www.academia.edu/13123375/Ensiklopedia_negara_ sudan diakses 27 Des 2016 pukul 9:53 WIB

M. Syafe'ei El-Bantanie, Gampang Praktek Zakat Infak Sedekah, Kawah Media, Jakarta, 2009.

Muhammad Hasan, Manajemen Zakat Model Pengelolaan yang Efektif, Idea Press, Bantul, 2011.

Tim Kementerian Agama, Modul Penyuluhan Zakat, Kementerian Agama RI Dirjen Bimbingan Masyarakat Islam Direktorat Pemberdayaan Zakat, Jakarta, 2013. 
Aulia Candra Sari

Undang-Undang Zakat Sudan tahun 2001.

Yusuf Qardhawi, Hukum Zakat, terj. Salman Harun dkk, cet. XII, Litera AntarNusa, Jakarta, 2011. 